Flows, Circulations and their Opposites: Ethnographic Perspectives and Theoretical-Methodological Challenges

\title{
Interpreters of difference: "Universal" communication and the national body of Brazilian artists in the USA
}

\author{
Bernardo Fonseca Machado' \\ ' Universidade Estadual de Campinas, Instituto de Filosofia e Ciências Humanas, \\ Departamento de Antropologia, SP, Brasil
}

\begin{abstract}
Centered on examining the trajectories of Brazilian actors who migrated to the United States with the purpose of studying and working in that country, this article aims to discuss the rhetoric of difference mobilized by subjects to describe states, markets and their own experiences. The proposal is aligned with anthropological research focused on investigating the politics of difference in transnational contexts. During 2015 and 2016, I conducted interviews with eleven Brazilian artists who lived in the USA. These individuals argued that there was a "universal" communication conferred by "art" and relied on the transcendence of their acting techniques - they believed they were capable of playing any character in the new country. However, as they tried to obtain roles, they encountered restrictions precisely because they were foreigners: their accent, physical appearance and the visa-related limitations prevented them a regular professional practice. The main question is: how these subjects formulated about difference?
\end{abstract}

Key words: Discourses of difference; actors; theater; Brazil; United States. 


\section{Intérpretes da diferença: \\ A comunicação "universal" e o corpo \\ nacional de artistas brasileiros nos EUA}

\section{Resumo}

Centrado no exame das trajetórias de atrizes e atores brasileiras/os que migraram para os Estados Unidos com o propósito de estudar e trabalhar naquele país, este artigo tem como objetivo discutir as complexas retóricas da diferença mobilizadas por sujeitos para descrever Estados, mercados e suas experiências. A proposta está alinhada a pesquisas antropológicas interessadas em investigar as políticas da diferença em contextos transnacionais. Realizei entrevistas com onze artistas brasileiros/as que moravam nos EUA, entre 2015 e 2016. Essas pessoas defendiam existir uma comunicação "universal" conferida pela "arte" e apostavam na transcendência de suas técnicas - consideram poder interpretar qualquer personagem no novo país. À medida que tentavam obter papéis, perceberam restrições justamente por serem estrangeiros/as: o sotaque, a aparência física e o tipo de visto impediam o pleno exercício profissional. A pergunta central é: como esses sujeitos formulavam a respeito da diferença?

Palavras-chave: Discursos da diferença; intérpretes; teatro; Brasil; Estados Unidos 


\title{
Interpreters of difference: \\ "Universal" communication and the national body of Brazilian artists in the USA
}

\author{
Bernardo Fonseca Machado
}

Theater is usually seen as a local phenomenon, limited to a specific region. ${ }^{1}$ However, shows, artists and texts have been in intensive transit across the globe since at least the nineteenth century (Balme 2012). On some of these trips, actors are enchanted by the new territory and start living and working in the local theater market. These migrants exercise a profession in which (in most cases) they perform an "other" - a character - in a territory where they are foreigners. When traveling, they provide depth to roles mobilizing multiple social references and, therefore, invite an anthropological discussion of the relationship between migration and alterity. What challenges do they face in their profession? How are their bodies perceived? What strategies do they mobilize to circumvent any restrictions?

In this article, I discuss the trajectory of Brazilian actors who migrated to the USA with the purpose of studying and entering the entertainment market in that country. The purpose is to work with the complex rhetoric of difference mobilized by subjects to describe states, markets and their own experiences.

My interest in the theatrical sphere as a field of research is not new. Since 2010, I have conducted investigations regarding the meanings and effects of theatrical practices as a social phenomenon. Between 2014 and 2018, I developed my doctoral analyses in theater schools in São Paulo and New York investigating how stage performers materialized, produced, updated and negotiated the most diverse social repertoires (Machado 2018a). Regarding experiences outside Brazil, I have scrutinized about the migratory practice of female and male actors on two occasions. The first, in partnership with Lilia Schwarcz, in which I analyzed the way artists dealt with the distance between their initial expectations and the conditions they experienced. Thus, we investigated how notions of time were managed in these actors' migratory projects (Machado \& Schwarcz 2017). The second, I scrutinized the racial classification process of female Brazilian actors in the US market (Machado 2018b).

Here I explore how these artists in transit handled and produced a rhetoric of difference. The performers defended a "universal" communication conferred by "art" and valued the transcendence of their acting techniques - they believed they were capable of playing any character in the USA. As they tried to obtain roles, however, many perceived restrictions precisely because they were foreigners: their accent, physical appearance and type of visa prevented full professional practice.

The proposal is therefore aligned with anthropological research concerned with discussing the politics of difference. Bela Feldman-Bianco (2001), for example, analyzed how Portugal and Brazil produced similarity and alterity in two distinct political moments in the 199os. Igor de Renó Machado (2012), in turn, dealt with the "management of difference" in Portuguese and Brazilian legislation concerning the entry, permanence and departure of foreigners with regard to their territories. Inspired by their work, I propose a small shift:

\footnotetext{
This text is an improved and abridged version of chapter 5 of my doctoral thesis entitled "Atos da Diferença: trânsitos teatrais entre São Paulo e Nova York no início do século XXI" [Acts of Difference: theatrical transits between São Paulo and New York at the beginning of the twenty-first century] defended at the Graduate Program in Social Anthropology of the University of São Paulo (PPGAS/USP) in 2018 under the supervision of Prof. Lilia Schwarcz and funded by the São Paulo Research Foundation (FAPESP; grant no. 2014/15902-2). These reflections continue in my postdoctoral research - also funded by FAPESP (grant no. 2019/08713-2) - in which I investigate how the bodies of artists are qualified in terms of gender, race and sexuality based on the ideas of "theatrical truth" and "representativeness". I would like to thank the two blind reviewers and the English revisions made by Sebastián Ramírez and Thomas Lemouche.
} 
instead of focusing the reading on government attitudes, I try to understand how Brazilian migrant artists mobilized the notions of difference to explain the qualities the US State and the entertainment market attributed to them. With that, I discuss forms of presentation, classification and self-perception in a universe of multiple representations.

\section{Theatrical routes: migrate and interpret}

Since the nineteenth century, theatrical shows have been conceived and produced with the intention of serving the fledgling entertainment market in numerous cities worldwide. The plays formed part of the imperialist, colonial strategies of expanding European standards beyond their territories (Balme 2012, 2015).

In more recent years, new routes have been consolidated. Over the span of a little more than a decade, an organized system of Broadway shows on tour was set up in a large number of countries, including Brazil (Machado 2018a). New York has established itself as a center for the diffusion of musicals. In São Paulo, a number of factors, such as, legal conditions, business interests and the fascination of part of the artistic class have come together to deepen commercial relations with the USA and facilitate economic, aesthetic and social exchanges. Within the context of expanding Broadway plays in Brazil, American theatrical-symbolic imaginaries stimulated a group of young people to try to work abroad.

Regarding migratory relations between Brazil and the United States, in 2014, the American Community Survey (ACS) ${ }^{2}$ estimated that for a period of just over 20 years, the number of Brazilians living in the USA had increased from 82,485, in 1990, to 335,608, in 2014, a 307\% increase (Lima \& Castro 2017). In the same year, 2014, the Brazilian Ministry of Foreign Affairs (MRE) estimated that 1,368,300 Brazilians lived in the United States, ${ }^{3}$ based on data from its consulates in North America. The discrepancy between the numbers reveals the difficulty in computing the exact number of national migrants in foreign lands. In the following years, the percentage continued to grow: in 2000, Brazil had the $28^{\text {th }}$ largest migrant community in the US (U.S. Census 2000), and by 2014, it held the $19^{\text {th }}$ place (ACS 1 - Year Estimate 2014). It is important to remember that, although the migration of actors to the USA seems an anomalous and uncommon act, it is inserted in a broader migratory context. The four sectors that most employ Brazilians in the United States are "Professional, Scientific and Technical Services" (18\%), "Construction" (13\%), "Other Services" (12\%) and "Arts, Entertainment and Recreation, Accommodation and Food Services" (11\%) (Lima; Castro, 2017); male and female actors fall under the last heading.

In the anthropological literature of the past two decades, a growing body of research has focused on Brazilian migrants around the world (Sales 1999; Piscitelli 2007, 2013; Machado 2008; Dias 2009; Assis 2011; Tiriba 2017). These are works committed to understanding people's relationships with the State, their economic motivations, what experiences they face and the like. Some research, dedicated specifically to Brazilians living in the United States, is centered on the constitution of a "national identity" in contrast to their new reality (Riberio 1999; Beserra 2007; Margolis 2009). Although they follow distinct approaches and investigate numerous scenarios, these works reveal the complexity in dealing with the subject and indicate certain paths to be followed.

\footnotetext{
2 This is a division of the U.S. Census Bureau that regularly collects information and updates the data produced by the United States government on its population profile.

3 Data obtained at <http://www.brasileirosnomundo.itamaraty.gov.br/a-comunidade/estimativas-populacionais-das-comunidades/estimativaspopulacionais-brasileiras-mundo-2014/Estimativas-RCN2 014.pdf>.
} 
In order to select actors for my interviews, I spoke with an acquaintance who had moved to New York in 2010, precisely to take a course in theater. She told me a little about her life and provided the emails and social media addresses of Brazilian artists she knew. ${ }^{4}$ I got in touch with these people and made appointments. I interviewed six women and five men. The youngest, was 18 years old, and the oldest, 35 . The age of the interviewees contrasted with the average age of Brazilian migrants in the USA, which was 39 years, according to the American Community Survey (ACS 2014). Most of the actors interviewed - seven - were between 20 and 30 years old in 2015. One year after the interviews, at the end of 2016, I considered it relevant to select some subjects to evaluate how they compared the migratory experiences after our initial conversation. Thus, I got back in touch with three people: two women and one man. The women still lived abroad and the man had returned to São Paulo.

Throughout the text, I present these subjects, paying particular attention to their trajectories, discourses and singularities.

\section{The educational difference}

Vicente landed in New York in January 2011. ${ }^{5}$ Born in 1984 , he was betting on a professional change. Born in a large city in the state of São Paulo, his father is a lawyer and an accountant, while his mother had been a teacher and later became a psychologist. From an early age, he had nurtured the dream of living in the American metropolis and building an international career. At 27, his professional experience was vast: the actor had already worked with important theater companies in São Paulo and had played prominent roles for a TV station that produced soap operas.

The travel plan derived from a diagnosis regarding the educational establishments in his country of origin: "Brazilians don't have a model of interpretation (...) I came here to study methods of interpretation and to develop into a better actor." As the young man explained to me, the acting technique in Brazil is the result of a poor mixture of procedures: "it draws a little from the European model, and a little from the American." The actor resented not having a methodology that originated from his native land that could give him more acting tools.

Jessica's opinion seemed in tune with Vicente's. Born in 1990 in São Paulo, she had dreamed of being an actor since childhood. Her parents were doctors - her father, a cardiologist and her mother, a neurologist - who had enrolled their daughter in a ballet course while still a child. As she grew, she wanted to know more about the new fad in São Paulo - Musical Theater - so she signed up for a free course. For two years, she actively participated in ongoing amateur productions, but it was a "shitshow": "people didn't arrive on time, didn't rehearse collectively...." At the same time, a new school opened its doors in the state capital that promised to properly train aspiring performers for the new market of musicals that was heating up. In the first year, however, the experience did not meet her expectations. The administrative disorganization and academic inconsistency of some of the teachers disappointed the young woman. A dilemma started to trouble her: "nothing worked in Brazil and I wanted to be an actor in musical theater. What should I do?" Her mother embraced her anguish and supported her search for institutions outside the country. Jessica progressed in her search and was accepted at an American drama school, which ensured parental authorization for her to move to New York and student visa. Initially, she would stay three months. The short journey gained momentum and since 2011, she has resided in the city.

\footnotetext{
4 At the time, I was conducting research abroad, supported by a grant from FAPESP (no. 2015/04818-3).

5 Names and certain details have been changed throughout the text to protect the identity and privacy of the individuals concerned.
} 
These two experiences are representative of the assessments made by a large portion of the migrants I met. Both Vicente and Jessica took their individual trajectories and generalized them as an example of "Brazilian" theatrical pedagogy. The country was perceived to lack technique - "it has no method of its own" - and as a nation lacking in order - "it was a shitshow." My interviewees did not list any national educational institution that could offer what they wanted. In Jessica's assessment, "They [Americans] are learning something that we [Brazilians] are not learning. (...). I think that's the difference: it's the education, it's the teachers, it's the culture."

Once in the classrooms, young Brazilians commonly encounter their first unforeseen circumstance: "They sing and dance when they leave their mother's belly," complained Jessica. Americans' premature theatrical initiation called into question the aspirations of numerous migrants. To pursue a career in the musical theater in Brazil, I was told, extra economic support was needed: "So you want to be that [a musical actor]? Then expect to graduate from college, or pay to do it as an extracurricular activity. And not everyone has the money to do it." The availability of economic resources depended on the subject's own trajectory. Imagining yourself on the New York stage was not everyone's privilege.

However, the assessment with regard to American students was not unanimous. Otávio lived in New York between 2013 and 2015, with a view to improve his acting techniques. He moved there aged 25, after graduating from a bilingual school in São Paulo and attending a prestigious acting course in the same city. Even so, he lacked security as an artist: “I knew a lot, but I didn't feel I had ownership of anything." American procedures, he believed, would make him "a better artist." One year after our first interview, back in São Paulo in 2016, the actor took stock of the experience. With regard to American technical procedures, he reiterated the opinions of his fellow countrymen: "they develop their skills earlier than us." On the other hand, he said: "Americans have no reference (...). [They] knew all the films and plays in the theaters, but they knew nothing about more experimental and cutting-edge theater." The repertoire of different theatrical aesthetics qualified his knowledge as a currency of distinction. Actors in Brazil - "more theoretical" and "very academic" - had some comparative advantage in relation to the Americans. Even though the excess reflection on the part of these artists resulted in a creative paralysis: "One thing I miss about the Americans is how they make things happen: taking a scene, knowing how to analyze and bring it to life."

A majority of my interlocutors shared a sense of enchantment and fascination with US educational establishments. The techniques and the foreign organization were valued for providing a superior result, in their opinion. The Americans themselves were the result of this unique "education." ${ }^{\circ}$ Despite the initial difficulties, young artists completed the courses and, not infrequently, decided to extend their stay. Their reasoning took into account the benefits and setbacks of staying in the destination country and also the possibilities and advantages of returning to the cities of origin. Migrant actors wanted to do auditions, expand their opportunities and, who knows, get a role in a production. The American market looked promising.

Brazilian men and women assumed that, by attending educational establishments in New York, they would guarantee the necessary attributes to compete. However, children and adolescents from the US educational system received sophisticated stage training from an early age and showed a familiarity with the musical productions environment. My interlocutors did not characterize this knowledge as an insurmountable "natural gift", they believed they had the abilities to move swiftly through the stages and match their competitors, despite the unequal footing resulting from their educational experience in Brazil. The difference could be overcome, after all, since acting was seen as transnational and "universal", they could find work.

6 In her research on Brazilian graduate students in Europe and the USA, Claudia Barcellos Rezende (2009) drew attention to the enthrallment experienced when face with universities and local values. 


\section{Between the State and the market: a legal difference}

While the actors trusted their artistic qualities and their ability to learn, they also identified restrictions beyond their control. During the interviews I conducted, almost everyone mentioned the difficulty in obtaining permission from the foreign government to work. As I explained in a previous article (Machado \& Schwarcz 2017), there are numerous legal requirements. Travelers who enter the country on a student visa can extend their stay through an OPT (Optional Practical Training) without major bureaucratic obstacles. It is a document that allows non-American citizens to exercise the profession for a year in the country after having graduated from a course. Following the "training" interval, the deadline ends and professionals have to return to their country of origin, unless they request an $\mathrm{O}_{1}$. This is a visa for workers with "extraordinary skills" in the areas of science, arts, education, business, athletics or "extraordinary achievements" in television and film production.

Brazilians experienced these obstacles in a unique way. The American entertainment industry presented itself as an open and attractive market, however, the bureaucratic structure of the United States guaranteed market reserve for its domestic artists. After Vincente graduated from the course he had enrolled in, he received warning from a casting agent: “foreign artists, if you don't have a green card, you can't work.” Initially frustrated, the Brazilian did not want to give up and decided to request documentation from the American authorities?. Bureaucracy in the land of Uncle Sam demanded a document that detailed Vicente's long career on the stage and screen in his native country. The Brazilian consulate was required to issue a letter of confirmation with the proper letterhead. A few months after applying, however, the young man had not received the necessary documents from his country to obtain the desired visa. The actor interpreted the failure to issue the statement as negligence: "the American government has given me more [than the Brazilian government]. My health insurance has expired, and I joined Obama Care. ${ }^{8}$ Since then, the United States has been paying for me to have quality of life, to be successful. And the government of my country can't sign a letter for me?"

The outrage was such that it spilled over to other sectors. He then listed the labor market problems in his homeland: "Brazilian actors have no support whatsoever." National cultural policies would always result in failure: "the law that supports culture is a bust," "actors are hostage to two TV stations," "actors have no platform for anything." In comparison, the United States offered opportunities to work in series, films and plays: "here it looks like they want you to be successful. And in Brazil, I don't feel that." Interestingly, the actor transferred responsibilities, and considered that the bureaucratic barriers experienced in the country of arrival ought to be resolved by his state of origin. Or even that Brazil, with its precarious cultural policies, had a market that was so problematic it justified facing all the legal obstacles in the USA. It is worth noting the nations were qualified differently and the burden of barriers was assigned to the country of Vincente's birth.

The sacrifice was worth it, confirmed Jessica. After all, in Brazil "there are a lot of cliques. Here too. But there you have to know everyone to get in." She explained: "Brazilians don't know how to cast." She narrated how an acquaintance of hers had been chosen for a role for which she was not prepared. Another candidate, who was more apt for the challenges of the character, was disregarded because the show's producers knew a particular actor auditioning. In Jessica's eyes, the objective examination of theatrical technique had been relegated to the background. In the American market, on the other hand, she considered the attitude was different: "They make money from this, it's an investment."

Rita's position diverged appreciably from her countrymen. The Campinas native was born in 1989, her mother worked in an NGO and her father was a real estate agent. In Brazil, she studied at an American school and moved with her parents to the state of Florida early on. Citizenship in the United States arrived in 2006:

\footnotetext{
The United States Permanent Resident Card, popularly known as the green card, guarantees more rights for the migrant: it does not expire and classifies the individual as a permanent resident in the United States.

8 Formally known as the Patient Protection and Affordable Care Act, it is a federal law signed by then President Barack Obama on March 23, 2010. The legislation regulates health insurance prices and expands public and private insurance to the American population.
} 
the father had invested a large sum of money to start a company and, in return, the government granted green cards to the whole family. Entering a private college in New York meant she was able to work as an actor in musical theater. In years that followed, she paid her bills with the training she offered to teenagers applying to attend theater universities across the country.

Rita confessed to helping aspiring Brazilian actors who faced bureaucratic impasses in the new land. To grant or renew the $\mathrm{O}_{1}$ visa, the US government requires that actors have jobs scheduled for two years following the date of application for the document. "That's impossible," she told me. For this reason, she invented projects and sent letters addressed to the American migration office signaling her interest in working with her Brazilian compatriots. The plays almost never reached the stage.

While the majority of my interlocutors emphasized the broad market for musicals in New York, the situation delineated by Rita was somewhat different. The young woman recognized that there are many plays in the city, but she said: "there's very few plays that pay." Since graduating in 2012, her income depends primarily on working as a baby-sitter and coaching teenagers looking to enter college. Whereas working in a professional theater company offered her no financial return. Comparing her trajectory with that of colleagues who have acted in major musicals, she explained: "It's complicated, because I have friends who are working on Broadway. They're earning a very good salary for the theater, [but] for the real world it's low."

In this regard, according to data from the Bureau of Labor Statistics of the US Department of Labor, in the first half of 2016 - the period in which I conducted the interview with Rita - the average weekly wage for an American worker was $\$ 823.00$ (US Department of Labor 2018: 5). Based on a simple calculation, if an individual worked 48 weeks a year, they would receive gross earnings of US $\$ 39,504.00$. In contrast, according to data from the annual report of the American actors' union, for the 2015-2016 season (which corresponds to the second half of 2015 and the first half of 2016), actors were paid a median of US $\$ 7,789.00,{ }^{9}$ per year. Clearly, while the comparison may require greater statistical care, this attests to the argument made by Rita: even on Broadway - the peak of a theater actor's career in New York - the earnings were not so promising.

In addition, Rita reflected that in order to work in entertainment in the USA, you had to join the theater artists' union. Actor's Equity charges an initial fee of US $\$ 1,600.00$, an annual fee of US $\$ 170.00$ and members are required to contribute $2.375 \%$ of their wages. In return, the union claims to exercise protection for its affiliates from the producers. The actor also explained to me that there were three types of auditions. Two of them were intended exclusively for union members and a third type was open so that anyone - unionized or not - could try to get the role. At auditions organized by and for the union, there is a list of 150 to 250 people who will be seen, but those who are not union members are not called. Familiar with New York's competitiveness, Rita explained how plans to participate in the scene stumbled on legal obstacles. Broadway's own salaries, while showy for Brazilians/migrants, were tiny (and unstable) when compared with other professions.

Upon becoming aware of the importance of the union, many Brazilians were informed about the procedures for joining. The surprise was a "cold shower," as Vicente said. To join Equity, it was necessary to have a green card, and the criteria for obtaining that were highly restrictive. Although the horizon initially presented itself as broad and promising, it soon gained a limited framework. Vicente and Jessica, for example, both gave up theater and directed their efforts toward cinema and television, whose actors' union was more flexible in relation to international artists.

\footnotetext{
9 The union chose to adopt the median and not the average value to prevent the high salaries of big stars from impacting the data (DiPaola 2016).The median is the value that separates the largest and the smallest half of a sample, i.e. it corresponds to the value in the middle of a data set. For example, in the sample $2,5,7,8,9,15,230$, the median is 8 .
} 
Migrants described the American market either as an example of liberal autonomy or as an environment under the protectionist scrutiny of the State. Sometimes they understood that there was "room for everyone," sometimes they highlighted the existing bureaucratic "barriers." The coexistence of these two narratives is indicative of the ambivalent and intricate relations that the American imagination produces and the State implements. While, on the one hand it promises space, on the other, it imposes legal mechanisms for these subjects. Following the logic of this imaginary, obtaining work emerged as the result of much merit, commitment and sacrifice.

In contrast, the Brazilian musical theater market was described as inefficient and narrow-minded. The low degree of professionalization could be measured by the selection process - too personalized - or by the lack of financial conditions to earn money. Even so, there were those who suggested some optimism: "I think they'll get somewhere eventually," said Jessica. From this perspective, Brazil - as a national entity and with no regional hue - was learning to increasingly professionalized itself, after all, it was equipping their nationals with foreign resources and references.

Actors based in New York considered individual effort a determining factor for a successful outcome. Initially, they claimed the difference in their education compared with their Americans counterparts was due to structural inequality - "they" had classes at school that could only be obtained in Brazil through sufficient economic resources. Then, the children of Brazilian urban middle classes relied on their own qualities to overcome this disparity. The difficulty in obtaining recognition in the USA was attributed to competition, to cultural particularities of the USA, to market barriers and to state bureaucracy; however, paradoxically, personal artistic attributes or professional qualities were almost never considered a decisive element in their trajectory. Subjects used to explain the return to Brazil in terms of resolve (or failure): "an individual will leave if they don't have enough drive to stay," they said.

The obstacles of the State and the foreign market, although recognized, were not translated as impossible to overcome. It seemed inconceivable for them to justify the difficulties in terms of national aptitude: "Brazilians aren't fit for the North American artistic market." Given the profession they exercised, actors assumed they were able to learn and compete equally in that environment. Moreover, the desire was to get a job in which the character was American. Thus, they would attest to their qualities: sufficient technical skills to play any character, regardless of nationality. However, they did not account for how the Americans would read their bodies.

\section{The difference in bodies}

As they attempted to find roles, the actors realized how they were generally classified as Latinos/as due to their physical shape and Portuguese accent. Despite the rhetoric of a universal interpretation, their appearance made them reduce and reevaluate their plans for work and success in the United States (Machado 2018b).

Since arriving in the new country in 2014, Lucas has sought work in the so-called "physical theater," that is, shows in which body partiture is the form of narrative expression - which does not depend on text. He was born in Porto Alegre in 1980 and at age of 14 moved to São Paulo. His father worked as a businessman in a multinational company and his mother was a teacher. Enrollment in a professional actor course at a prestigious private school in São Paulo intensified his interest in the stage. He became known in the entertainment industry after working for several theater companies and major musical productions in São Paulo and Rio de Janeiro, but a passion for Broadway shows led the young man to New York, in 2011, where he lives today.

In 2015, Lucas was shortlisted for a casting audition of a new show. In the production there was no dialogue, the actors presented the intrigues of a family using body language alone. The Brazilian was one of 30 artists who performed. In the first stage of the casting process, the production discarded 22 people and kept the young 
man in the process. After further tests, in front of the group of actors, those responsible said: "we're looking for a very specific type, so we're going with this one." The Brazilian explained the reason for the selection: "the guy looked like... he was half Latin, half Arab. He was very ethnic. Well, it wasn't for me anyway. He and I will never compete for the same role.”

Among the interviewees, Lucas was the only person with light-colored hair and eyes. The actor's resume, available on the Internet, described his appearance as: $1.75 \mathrm{~m}$ (5'9"), $70 \mathrm{~kg}$ (156lbs), an "athletic, toned" body, "blond hair" and "green eyes." When I asked him about his "color"|"race" he responded with other questions: "White? Caucasian?" As a Brazilian living in the USA, he pondered what form of classification to use. In his country of origin, he was categorized (and was understood) as white; in New York, he translated that as Caucasian. The term "Latin" was way outside Lucas' consideration, even though the word is often used to define Brazilians in the USA (Beserra 2005, 2007; Margolis 2009). Perhaps it bothered him to be assigned to that group. Some studies show how certain Brazilians highlight their difference in relation to Latinos and Hispanics in terms of their work ethic, physical appearance, social class, education, language and culture (Sales 1999; Beserra 2005, 2007; Margolis 2009). ${ }^{10}$

From the outset, however, production for the show had probably intended to select an actor whose physical traits were read as "ethnic" - at least by American standards. Lucas' nationality may have been an element in his favor in the recruitment process for the audition; however, at least in the justification he received, the team expected someone with physical characteristics different from those present by the actor's body. In 1999, the Tomás Rivera Policy Institute (TRPI) - an academic research center based at the University of Southern California - listened to the community of Latino workers in the American entertainment industry and developed a report, the conclusions of which were decisive: "Latinos need to fit a certain stereotype to be selected as Latinos [...] [those] who do not fit that stereotype do not receive Latino roles" (Pachon 2000: 4-8).

When he finished telling the anecdote, I asked him whether there were any other obstacles he had faced in his search for work in the New York theater entertainment. "I have an accent when I get nervous," explained the actor. "I've been doing more physical things than text [...], so everything has worked out." The investment in a career closer to the circus and physical theater was strategic. The only feature that highlighted Lucas' nationality, ethnicity or race - his accent - was silent on stage. Even so, this was not a dream occupation, since the vast majority of people longed for a prestigious role in a show, preferably with many lines.

Among the interviewees, only one young man reached the American stage. A native of Brasilia, Amilton was born in 1993, the son of a civil servant and a businessman. In 2013, Manhattan became his home not long after he enrolled in an acting course. After two years in New York, he joined a large show, performed on a tourist cruise ship on the Mediterranean Sea. The contract was for the interpretation of a drag queen ${ }^{11}$ in the musical Priscilla, Queen of the Desert. For the character - one of three protagonists - Amilton had to walk around in six-inch high heels, wear a corset and shave his legs. During the interview, the young man classified himself as "white" and, on his personal website, in the USA, he stated he was $1.77 \mathrm{~m}\left(5^{\prime} 10^{\prime}\right)$, with "brown hair" and "brown eyes." The cast was composed exclusively of people whose "mother tongue" was English, except for the young Brazilian. As the actor declared, his accent was barely noticeable. Amilton got a prestigious job in the eyes of his countrymen, perhaps because he was white and did not appear Latino, or because his Brazilian accent was almost imperceptible, or because the character was a sensual drag queen.

It is worth investigating Amilton's success in light of the literature that deals with the social meanings of transvestism and drag queens. According to Esther Newton (1972), between drags, there is a double inversion of "appearance and illusion": while the exterior appears feminine, the interior (the body) is masculine and,

10 For an introduction to the constitution of the "Latin" category in the USA, see Nicholas De Genova and Ana Ramos-Zayas (2003).

11 Here I use the emic classification, present in the play and in his words. 
at the same time, while the exterior appearance is masculine due to the bodily form, the subjective essence is experienced as feminine. From a similar perspective, Paula Rodríguez Marino (1997) argued how transvestism was a central element of the narrative in some American films, such as Mrs. Doubtfire (1993), The Birdcage (1995) and Victor/Victoria (1982). Set in a comical tone, some of the characters in these productions cross-dress with a view towards hiding their "true" gender identity. Thus, when Amilton was in a scene interpreting a drag queen, a game of presentation and concealment was constituted. His ability to "imitate" or "interpret" gender was in the foreground. In this case, the actor's transvestism "eclipsed" other differences, or, at least, transformed Amilton's accent, nationality and race into less relevant factors - at least on the stages of the cruise ship allowing the young man to circumvent the rigid American classification system.

In any case, in the experience of these two men, overcoming their accent seemed to be fundamental for them to thrive in the competitive field. The same could not be said of women. Giulia's New York teacher expressly suggested that she keep her Brazilian accents with a view towards guaranteeing more job offers. The actor was born in São Paulo, in 1988. As a child, the family moved to New Jersey, where she lived from ages three to eight. Back in Brazil, in Salvador, the parents chose to fight their daughter's shyness with theater classes. A few years later, as a teenager, she decided to attend a vocational school for actors. After going backwards and forwards between schools, in 2010, she boarded a plane determined to spend three months studying in New York. After this initial period, she postponed her return several times until she assumed her new address.

In September 2015, the first time I interviewed Giulia, the way she was treated and designated in the US market bothered her deeply: "People look at me and judge me as a Latina. [...] And they classify you. This is the bad thing about the United States. They judge you a lot. They have to specify: 'you're white,' 'you're Latina,' 'you're Chinese.' They separate people into boxes" (Machado 2018b: 64). At the time, the actor was committed to not being assigned a definition that would restrict her work.

A little over a year later, in December 2016, we spoke again. Her consternation had taken on another dimension and she talked enthusiastically about her latest work. Her career route had been reevaluated after realizing the difficulties faced in gaining space in musical theater, as a result of the constraints of both the American visa and the union's fee. Aware that in television and cinema the laws were more flexible, she packed her bags and moved to another city. In Los Angeles, new contacts opened up horizons and the actor entered an unexpected niche: the Persian music market. A music video director repeatedly invited the young woman for several shoots in which she played the romantic couple together with a Middle Eastern singer.

In the United States, Giulia realized how her racial classification was both restricted and broad. Historical examination of the way in which Latino actors were cast for films and plays throughout the 2oth century offers clues to explain the diverse reading regarding Giulia's body. According to theatrical researcher Brian Herrera (2015), the selection of Latino artists in commercial films, television and theatrical productions in the mid-twentieth century documented the paradigms of racial intelligibility during the first decades of the Cold War. According to the author, the "Good Neighbor" policy adopted by the United States developed a series of strategies to place Latino artists in the American entertainment market. Mexican, Puerto Rican and Cuban actors were useful for producers and directors, because, according to the classification framework of the period, their bodies allowed a racially malleable reading. These artists performed two tasks: on the one hand, they guaranteed authenticity for characters designated as Latino; on the other, they were used to interpret multiple "non-white" characters. The entertainment industry explored the notion of an uncertain or mixed "Latino" race with the aim of increasing the legibility of their bodies. Taking the trajectory of Puerto Rican

12 The "Good Neighbor" policy was introduced by President Franklin Roosevelt to describe the diplomatic line that guided his administration (1933-1945) in relation to Latin America. The purpose was to encourage and guarantee commercial, cultural and military exchanges between neighbors. 
actor Rita Moreno ${ }^{13}$ as an example, Herrera explains how, in 1956, she played an Asian descendant in the play The King and I. While in an episode of the 1958 television series Father Knows Best, Rita played an Indian student. In both characters, Moreno's ethnicity was extended beyond her origin and ancestry.

During the 196os, the Latino artistic community began to demand that the American film and theater industry stop selecting Latinos to interpret "other ethnicities." The claim, according to Brian Herrera (2015), paid off; however, as Giulia's discourse attests, in some circumstances it still seems acceptable to assign a Latina woman to perform a character of another ethnicity/race.

Despite these issues, the young actor seems to have adapted to the context. In her curriculum, in English, available on a foreign website, she classified herself as Hispanic, ethnically ambiguous and mixed race. When I asked her to explain why she was defined in these terms, Giulia said: "I think these are probably the ethnic groups that I can be cast for." The perception regarding her body was, in fact, broad: "I can be Italian, French, Brazilian, Mexican and, apparently, Persian." At the same time, she positively evaluated the scenario that was being delineated in the USA: "Now it's good. It's good to be Latino. They want to diversify more." In 2015, she told me how they still used to frame her as certain types of characters: "the sexy woman, the woman who cheated, the woman of the lead guy's dreams" (Machado 2018b). But, a year after our first conversation, now in 2016, she no longer considered this casting a problem, perhaps because she had requalified her expectations due to limited offers, or even because she saw potentialities in the American entertainment market that increasingly desired Latino artists. The only caveat she made was related to the accent: although agents and teachers insisted that she maintain her Portuguese accent, Giulia refused: “They don't know where I'm from. I don't have a typical Brazilian accent. But I also don't have a typical accent from here." Performing characters from multiple ethnicities/races was no longer a problem, but she did not seem to want to force her pronunciation either. A similar fact occurred with another female actor.

The first interview with Amanda took place in December 2015. At that time, I asked her which "color"|"race" she used to classify herself and she immediately replied: "On the certificate it says I'm brown, but I say I'm black. Put 'mixed'." When she worked in Brazil, she said she was recruited for black or white characters "depending on the wig" she wore (Machado 2018b; Machado \& Schwarcz 2017). Her curriculum available on the internet describes her as a "thin", $53 \mathrm{~kg}$ (118 lbs), $1.72 \mathrm{~m}\left(5^{\prime} 8\right.$ ") woman with "brown hair" and "brown eyes." One year after our first chat, on Christmas eve 2016, we spoke again, via Skype.

Over the course of an almost two-hour conversation, she brought me up to date with her news: during this time, she underwent an important audition. It was a television series whose main character "had to be a mix of Black and Asian." She explained that she was shortlisted after having sent a photo in which she looked "very Asian," even though she had no ancestry. Interestingly, during the audition, "I was told I was not black." Amanda was surprised, but persisted, asking to read the scene. The director's team accepted the proposal and enjoyed her performance, but was not convinced. The team said: "we want you for the character, but she needs to be black." Faced with the impasse, the Brazilian laughed: "look, there's nothing I can do to help you if you can't see it." Once again, the process of the racial reading of Amanda's body was at issue. Although the actor defended her black ancestry, the series team seemed to read the young woman as a Latina; that is, Amanda's ethnicity/race could be extended to Asian, but it would raise doubts if she performed the role of an Afro-descendant.

To get around this situation, the director asked the interpreter to read another role - a Latina Adriana - with a Brazilian accent. "That's something I don't know how to do," she explained to me, "since I learned English by listening," because she watched American TV series and copied the sound, "I don't have an accent."

13 Born in 1931 in Puerto Rico, Moreno moved to New York at the age of five and, at the age of eleven, began work as a voice actress dubbing American films in Spanish. During her career as an actor, she received an Oscar and a Golden Globe for her interpretation of Anitta, in the film West Side Story. 
Even so, the young woman volunteered to learn to imitate the national accent. The director was satisfied and confirmed her selection. The character was the villain of the plot, a "beautiful Latina," or "femme fatale," Amanda explained to me - "the Latina who is sexy, they always buy it." The "sensual Latina" category itself preceded and transcended the actor, the image contained a past memory reified by time and revised with each new selection of female artists. The expectations of directors and producers concerning Brazilian women are in dialogue with what Adriana Piscitelli calls "conventions of eroticization" (2007: 23), that is, attributes such as accent, hair, silhouette and facial features are perceived in such a way that they often trigger erotic responses in foreigners. ${ }^{14}$ The qualification caused Amanda discomfort - "I always find it annoying." However, after considering possibilities available to her in the market, she decided to take advantage of it: "this is the door that's open now, so why wouldn't I use if it's there?"

In the United States, the association between sensual practices and Latin women is perennial. According to the historiographic work of Brian Herrera (2015), producers of films and plays in the USA began producing a repertoire of imagery, sound and narratives concerning Latin people after the onset of the "Good Neighbor" policy, until then, these other republics of the Americas were absent from the stage. They only gained the spotlight in the 1930s and 1940s, and were characterized by striking colors, prominent rhythms and phrases that mixed English, Spanish and Portuguese. Taking stock of the issue, Herrera (2015) considers that these productions taught the American audience to identify what "Latinity" looked and sounded like, and how it made them feel. Although the constitution of this imaginary has certainly changed over the years, time has preserved certain analogies, like the fact that Latin women, and Brazilian women in particular, are associated with sensuality. More recently, migrant women from Brazil signaled discomfort due to the persistent relationship. For example, Bernadete Beserra's (2007) interlocutors, who lived in Los Angeles, complained about the direct association between their nationality and a possible natural disposition to sex.

In the second decade of the twenty-first century, this approach seemed to take on other forms. The identification with "Latinity" sometimes appealed to and sometimes repelled my interlocutors. Amanda perceived being cast for characters qualified as "sexy" as a restriction: "I always had the idea of being an actor to become other people. To be different. I like to create characters where it's not clear to you that I can play."

The conflict between a potentiality for "universal" interpretation and physical "particularity" - defined in terms of race, gender, age and nationality - impacted the female actor's projections. During our second interview, Amanda repeatedly explained discomfort in the way her body was epitomized, "if the job is to be who I am every day, it's no fun... I'm a tall, thin, singer and dancer every day. And then everyone sees that as 'oh, how cute she is when dancing.' I don't want people to look at me and think I'm cute." Even so, Amanda grudgingly calculated the benefits of fitting into the prevailing imaginary regarding Brazilian women, which made her life easier and allowed her to get jobs.

In previous articles, I explained how actors were defined in terms of nationality, race, gender and sexuality (Machado 2018b; Machado \& Schwarcz 2017). Arriving in the USA means for most people - especially female actors - being "racialized." For some migrants, when they were in Brazil, race was not reinforced as a striking diacritical trait. However, in New York, the same actors were readily classified in terms with which they did not identify.

I want to emphasize here how men and women explained a certain shift in their position in the market. Lucas obtained works in which there was a dissociation between his body and his voice, he began to claim space in physical theater and circumvented the obstacle of his accent - his opportunities were associated with his vocal silence. Amilton's transvestism on stage transformed his gender presentation into a more

14 Research by Susana Maia (2009) has contributed to contextualize the sexualized and racialized readings of Brazilian and Latin women in New York. 
relevant element than his accent. As if gender had momentarily shifted race and nationality from frontstage to backstage. Thus, he was able to pierce, at least on that occasion, the difficult frontier that limits the entry of Brazilian artists into the American market.

It is noteworthy how, during the interviews, the men classified themselves as "white." In the shift between countries, they do not seem to have undergone a process of "racialization" like the one experienced by the women. In their case, nationality was not coupled by a "racialized" perception of what was expected of a Latino or a Brazilian. Women's bodies, on the other hand, were defined by an inherent "Brazilianness." Identified as Latinas, they were required to reinforce this attribution with their own accent, in order to guarantee entry into the sector.

Accepting the challenge to participate in the American entertainment market, migrants identified the difference in their bodies and in the roles they could claim. The body assigned these actors to a restrictive set of characters. Despite this, the subjects resorted to another argument to indicate their artistic advantage.

\section{Emotional difference}

Emotional rhetoric was used intensely by the subjects, feelings emerged as substances that were either favorable or harmful to work, but intrinsically related to Brazilian nationality. If the technique could be learned, the bureaucracy overcome and the bodies assigned, the emotions were unavoidable.

Several times during her interview, Priscila repeated: "I'm very gringa." Born in 1990 in Campinas, a city in the interior of São Paulo, aged less than one month, she gained refuge in Los Angeles, California. Her father made his career in bank administration and when he was transferred, his architect wife and two children went with him. After traveling back and forth between the two countries, Priscila returned to São Paulo as a young girl aged eight and was enrolled in a bilingual American school. Years later, a teacher encouraged the teenager to join a musical theater course offered in the elective curriculum. Gradually, her interest grew and so did her commitment.

Her first job was in a grand show and guaranteed her initial enthusiasm; "I was young and I was enchanted." A large portion of the production team was foreign, which led the young actor to compare herself to her fellow cast members: "Americans are very professional. Like, they get things done. Brazilians are also professional, but like all Latinos, their emotions are more involved in the decisions." The experience allowed her to draw important parallels: "for Americans, I can say something straightforward, without fear of offending. I can voice my opinion, my ideas." According to her, the same did not apply to all nationalities: "for Brazilians, I'm more careful with my words. Brazilian culture is more easily offended.” The actor reiterated, in several ways, that emotions were more prominent among her countrymen, and this characteristic required greater attention and caution during the communication process.

By the end of the season, she was already tired. Her interests had shifted and her desire called for a learning trip abroad. In 2012, with the help of her parents, she entered film school at a private college in New York. At the time of our interview, she took stock of the pros and cons of the course. On the one hand, the school was good and offered new interpretation techniques. On the other hand, she had become uncomfortable with her American colleagues. From her viewpoint, "Brazilians are emotional and know how to deal with emotions. And here, for six months, people needed to learn how to invade each other's space. In Brazil there's no space, you just invade." As an example, the actress contrasted the two cities stating that, in São Paulo, she had done exercises in which she had "rolled over the person"; while in New York, even "a 'hi' is from way off." In Priscila's discourse, emotions appeared either as a negative national characteristic or as a positive quality.

References to feelings persistently emerged among my interlocutors in the USA. Amanda, for example, identified this national uniqueness as an advantage: "Broadway is missing something [that theater] in Brazil 
has, and it always will. That is, an open heart on stage. A Brazilian on stage is the most beautiful thing to see." The comparison between plays performed on national and foreign soil should not be made only in aesthetic terms: "the plays that I saw there [in Brazil] don't have a lot of the things that they have on Broadway, and I understand that. But what I saw there, they don't have in any musical here." From this perspective, the national particularity resides in something that borders on the ineffable, that "which makes you tingle from start to finish. It's a truth. It's something that comes from within. It's not the plasticity of the technique, it's not the plasticity of the scenario, it's not the knowledge they have here. It's the truth that comes from within."

In her experience in the United States, she attended shows that "took [her] breath away." However, the actor amended: "you see the girl singing, so beautifully. But you don't see her heart. In Brazil you do." The young woman's goal, as an actor, was to ameliorate the lack of "truth" in the New York scene: "I want to do it here. Because I want to bring heart to their sweet perfection." The emotional availability of Brazilians was a decisive attribute for the work that was to be performed. Amilton shared the same perception: "In Brazil, we are very affective. And we let ourselves be seen by another and get involved with another in a more fluid and natural manner. Americans have more rules for the way they behave." The argument presumed a nation whose essence could be apprehended by a trait: the emotions.

On the other hand, there were those who considered that emotional excess compromised the work itself. For Lucas, the professional decisions made in Brazil were too "emotional," because producers felt betrayed if their preferred actors worked with someone they did not like. In this perspective, exaggerated sensitivity produced inefficiency, favoritism, protectiveness and other forms of deviation. Emotions were considered to be related to a lack of control, an absence of method and a deficiency in technical discipline. Only a market detached from feelings could generate vigorous economic growth. The underlying assumption was that professional activity and practices of intimacy were incompatible.

The sets of arguments concerning emotions coexisted and seemed to be in tune with the very uniqueness of the work performed by actors. Two dimensions were called into question: the exercise of interpretation on stage, and relationships behind the scenes. Emotions could not positively serve both environments. On stage, they were welcomed and desirable. In this case, at least for Amanda and Priscila, Brazilians had an advantage over Americans. Behind the scenes, affective relationships prevented the pragmatism seen as necessary and, in this respect, sentimental excess corresponded to an obstacle to the adequate performance for the market.

The argument that mobilizes emotions as a natural sign of Brazilians is not new. Claudia Barcellos Rezende (2009), for example, researched people who pursued graduate studies abroad, in countries such as the United States, France and England. In her work, the interlocutors defended national differences, suggesting that Brazilians were more spontaneous and emotional, characteristics used as synonymous for superiority. Emotions guaranteed a "vital force," an involvement, as opposed to detachment and indifference. The ethnographic research conducted by Igor de Renó Machado (2008) reveals how in Portugal there loomed an expectation that Brazilians are happy, friendly and cordial. The people understood as "more Brazilian" were those who knew how to samba, make feijoada, play football and "be happy." In this context, migrants became the "victims and agents" of a continuous manifestation of nationality, what Igor de Renó Machado (2008) called "active subordination" to stereotypes. In the case of actors in the United States, due to the particularity of the profession, exaggerated nationality could jeopardize future jobs; that is, if they were too "Brazilian," they might not obtain diversified roles and, therefore, would manifest an "active insubordination" to the referential of Brazilianness.

Following the argument outlined by Lila Abu-Lughod and Catherine Lutz (1990), I am not interested in defending which is the most affective nationality. Rather I am interested in understanding the context in which this rhetoric was triggered. Emotional speech is inserted in a dispute for power games. In the theatrical setting, discussing affective skill is essential, having or lacking emotions corresponds to the capacity to perform a scene properly. Either people were poorly prepared - because they are irrational and overly emotional - or highly 
qualified - because they are more truthful and sensitive. In a less evident way, migrant actors vied for their qualities in a market that insisted on closing its doors to them. While some affirmed a passionate Brazilian side, others denied it, valuing a technical rationality that allowed them to access jobs.

Regardless of the strategy people adopted, there was a consensus: Brazilians were emotional. The national brand possessed a "natural" difference compared with Americans. Interestingly, it was suggested that an alleged substance - emotions - would guarantee the possibility of translocal communication. Feelings, according to these actors, were a universal value.

\section{Final considerations: mobilized differences}

The actor's discourses compared countries, cities, interpretation techniques and people, mobilizing the most varied references. I am aligned with the stance of Avtar Brah (2006) for whom the concept of "difference" has multiple meanings and allows us to study how discourses are constituted, contested, reproduced and re-signified. Thus, it is not my intention to identify what the "biggest" difference between these countries is, rather to understand what resources were used to qualify and constitute them.

The subjects suggested the coexistence of multiple sets of distinction, which oscillated between degrees of difference and differences in the essence. A first type was translated by Brazilians using an educational rhetoric. Migrants considered that there was a difference in the type of learning available to Brazilians and Americans. Based on this argument, these individuals imagined that, once in American schools, they could take advantage of the proper techniques and overcome inequality vis-à-vis other foreigners. Within the students' imaginary, it is understood that the subjects could achieve exactly the same results if they shared the same educational institutions and were evaluated according to the same methods. Based on this argumentative key, the difference between students - Americans and Brazilians - resided in their degree of knowledge. Having completed the stages of self-improvement, everyone could compete equally in the market.

On balance, Brazil was invariably backward and at fault. In the discourse of these subjects, the United States was understood as a seductive land yet also exclusionary, given the market-imposed barriers, and curbing these actors' international aspirations. Further, a legal distinction persisted, which divided and classified people as citizens or foreigners. In this sense, migrants began to perceive a second type of difference traversing their choices and projections. Their bodies were understood to be different in their essence.

From the viewpoint of foreign producers, the rapid classification of migrant artists as a particular type of character ("the Latinos/Latinas") domesticated national differences, forged a Latin identity and excluded confronting the complexity of individual experiences and techniques. In addition, of course, to assuming that the "others" - the Latinos/Latinas - were similar in their difference compared with Americans. Brian Herrera (2015) comments on how in the musicals and films produced during the "Good Neighbor" policy, many of the scenes and songs assumed that the "other" American republics were similar to each other and maintained an important distinction in relation to the United States. The American bureaucracy procedure reinforced inequalities in access to the allegedly free labor market. The rapid assignment of migrant bodies to particular types appeased any fear of dealing with the unknown and assumed to know, in advance, what to expect from these "Latin" bodies.

Following this procedure, a neocolonial practice was reinvigorated. The celebration of the open market in the United States was more beneficial to Americans than to Latin artists since producers and directors understood themselves as liberals at the expense of actually offering real chances for migrants. In this game, the US protected its market, but declared itself a land of opportunities, in order to accommodate conflicts via a discourse with easy acceptance among Brazilian migrants. 
The immersion in an unknown racial classificatory system gained multiple explanations and produced diverse reactions by actors who seemed to be unaware of the meanings of "Latin" in the new country. Some Brazilians ceased insisting - as in the case of Otávio -, others fought for space - like Vicente - and there were those who had assumed the difference and played with it - like Amanda and Giulia. In addition, people who had economic resources sought to overcome bureaucratic obstacles. These subjects, due to their privileged, middle class position in Brazil, imagined transiting anywhere unimpeded. In their view, efforts to diminish their accent and sound like "Americans" would mitigate the racial difference. Irrespective, some bodies - mostly male - were assigned to the margins of the entertainment market, while other bodies - mostly female - were encouraged to emphasize their Brazilianness to advance their careers.

By understanding the manner in which these people were inserted in this market, we can discern how Brazilian actors were "used" or "discarded" by producers and, simultaneously, note the meanings that nationality, race and gender gained for these migrants. Except as universal notions, these concepts took on the contours of exclusion and some kind of inclusion, even if "exoticized."

For the State and market in the United States, bodies and nationality were different in essence, whereas emotions and interpretation techniques could be learned. Brazilian actors disagreed: the only essential difference lied in the affective temperament of Brazilians. Feelings were, at the same time, destiny and power. An ambivalent logic was present. On the one hand, in the migratory project, actors assumed that their artistic skills would enable them to interpret characters in any cultural reality. At the same time, they considered it easier to be more "emotional" compared with Americans. Emotions were "universal" and "particular" universal in communication, particular to the Brazilian experience.

Thus, on the one hand, the "less Brazilian" the greater the possibility of exercising the profession of artists. To ensure their employability, actors avoided claiming to be from a particular country - so they gauged the degree of the accent. In order to play "any character" they needed to control the alterity of their bodies. At the same time, some professionals pointed out that the "more Brazilian," that is, the more emotional they were, the greater their artistic advantages in relation to the Americans, who were described as "colder."

Under the rules of the stage and in a migratory experience, alterity took on a double connotation. Actors abroad wanted to materialize in their bodies, both a character and an "American" reference. The choice to perform these plays on the stage of another country was in dialogue with a form of particular sensitivity, according to which "imitation" was a mode of existence. It was certainly not a point-by-point mimesis, or a schematic copy, but the desire to materialize the "other" in the "national body" - in the very skin of Brazilians. There was a desire to belong and integrate the cosmopolitan "arts" and, thus, to be molded in the ideals of the "metropolis" with the desire to achieve a "universality." While Brazilian actors thought they belonged to a global community of artists, the eyes of the Americans saw only Latin bodies and Latin characters.

In the discourses of Brazilian actors, the two types of differences coexisted and were based on specific logics. On the one hand, the difference in training assumed a certain "universality": all people shared the possibility of development - Brazilians and Americans considered that everyone could learn. On the other hand, the difference in essence presumed a "particularity" that could not be overcome - for Americans, Brazilians were different in race/body and, for migrant actors, the distinction lay in the temperament of each "nationality." Simultaneously, artists in transit, producers and directors abroad imagined a communion in communication and in the sharing of emotions.

In leading with these operations, the subjects were able to benefit and negotiate. Actors performed displacements anchored in the will of another. A project of becoming. A being realized by not being, by its incompleteness and, therefore, as a highly volatile act. As a difference in a continuous state of transit. 
Received: January 31, 2020

Approved: February 18, 2020

Translated by Phill Badiz

\section{References}

ABU-LUGHOD, Lila; LUTZ, Catherine (orgs.). 1990. Language and the politics of emotion. Cambridge: Cambridge University Press.

ASSIS, Gláucia de Oliveira. 2011. "Entre dois lugares: as experiências afetivas de mulheres imigrantes brasileiras nos Estados Unidos". In: A. Piscitelli; G.O. Assis; J.M.N. Olivar (org.), Gênero, sexo, afetos e dinheiro: mobilidades transnacionais envolvendo o Brasil. Campinas, SP: Unicamp/PAGU, 2011. pp. 321-362.

BALME, Christopher. 2012. "Histórias globais do teatro: modernização, esferas públicas e redes teatrais transnacionais". In: M. H. Werneck; A. C. Reis (orgs.), Rotas de teatro: entre Portugal e Brasil. Rio de Janeiro: 7 Letras. pp. 203-220.

. 2015. "The Bandmann Circuit: Theatrical Networks in the First Age of Globalization". Theater Research International, 40(1): 19-36. Available at: https://www.cambridge.org/core/services/aop-cambridge-core/ content/view/9DEBE7CF6117A01671EF70DooC580A75/S0307883314000546a.pdf/bandmann_circuit_ theatrical_networks_in_the_first_age_of_globalization1.pdf Accessed on January 302020.

BESERRA, Bernadete. 2005. "From Brazilians to Latinos? Racialization and Latinidad in the making of Brazilian Carnival in Los Angeles". Latino Studies, 3: 53-75. Available at: < https://ink.springer.com/ article/10.1057\%2Fpalgrave.lst.8600131> Accessed on January 302020.

. 2007. "Sob a sombra de Carmen Miranda e do carnaval: brasileiras em Los Angeles". Cadernos Pagu, 28: 313-344. Available at: http://www.scielo.br/scielo.php?script=sci_arttext\&pid=S0104-83332007000100014 Accessed on January 302020.

BRAH, Avtar. 2006. "Diferença, diversidade, diferenciação". Cadernos Pagu, 26: 329-365. Available at: <http:/| www.scielo.br/pdf/cpa/n26/30396.pdf> Accessed on January 302020.

DE GENOVA, Nicholas; RAMOS-ZAYAS, Ana. 2003. "Latino Racial Formations in the United States". The Journal of Latin American Anthropology, 8(2): 2-17.

DIAS, Gustavo Tentoni. 2009. "O processo de fixação do migrante brasileiro em Londres: a importância das práticas cotidianas na elaboração de sua identidade”. Ponto Urbe [online], 4. Available at: https:||journals. openedition.org/pontourbe/1427 Accessed on January 302020.

DiPAOLA, Steven. 2016. 2015-2016 Theatrical season report: an analysis of employment, earnings, membership and finance. Actors Equity Associations.

FELDMAN-BIANCO, Bela. 2001 "Brazilians in Portugal, Portuguese in Brazil: constructions of sameness and difference". Identities Global Studies in Culture and Power, 8(4): 607-650. Available at: https:/|www. tandfonline.com/doi/pdf/10.1080/1070289X.2001.9962710?needAccess=true Accessed on January 302020.

HERRERA, Brian Eugenio. 2015. Latin numbers: playing Latino in twentieth-century U. S. popular performance. Michigan: University of Michigan Press.

LIMA, Álvaro Eduardo de Castro e; CASTRO, Alanni de Lacerda Barbosa de. 2017. Brasileiros nos Estados Unidos: meio século (re)fazendo a América (1960-2010). Brasília: FUNAG.

MACHADO, Bernardo Fonseca; SCHWARCZ, Lilia. 2017. "Sonhos que migram: atrizes e atores brasileiros em Nova York”. Sociedade e Cultura, 20(2): 74-94. Available at: https:||www.revistas.ufg.br/fchf/article/ download/53066/25574 Accessed on February 202020. 
MACHADO, Bernardo Fonseca. 2018b. "'Latinas sensuais' - percepções sobre atrizes brasileiras nos Estados Unidos". In: G. Saggese [et al.] (orgs.), Marcadores sociais da diferença: gênero, sexualidade, raça e classe em perspectiva antropológica. São Paulo: Terceiro Nome/ Editora Gramma. pp. 59-76. . 2018a. Atos da diferença: trânsitos teatrais entre São Paulo e Nova York no início do século XXI. Tese de Doutorado. Faculdade de Filosofia, Letras e Ciências Humanas da Universidade de São Paulo São Paulo.

MACHADO, Igor José de Renó. 2008. "Sobre os processos de exotização na imigração internacional brasileira”. Revista de Antropologia, 51(2): 699-733. Available at: http://www.revistas.usp.br/ra/article/ view/27293/29065 Accessed on January 302020.

. 2012. "The management of difference: reflections on policies concerning immigration and the control of foreigners in Portugal and Brazil”. Vibrant, Virtual Brazilian Anthropology, 9(1): 311-322. Available at: http://www.scielo.br/pdf/vb/vgn1/11.pdf Accessed on January 302020.

MAIA, Susana. 2009. "Sedução e identidade nacional: dançarinas eróticas brasileiras no Queens, Nova York”. Estudos Feministas, 17(3): 769-797. Available at: http://www.scielo.br/pdf/ref/v17n3/v17n3aog.pdf Accessed on January 302020.

MARGOLIS, Maxine. 2009. An Invisible minority: Brazilians in New York City. Gainesville, Florida: University Press of Florida.

MARINO, Paula Rodríguez. 1997. "Travestismo: la construcción de la identidade de género sexual en algunas comedias norte-americanas". Intexto, 2(2): 1-12.

NEWTON, Esther. 1972. Mother Camp: female impersonators in America. Chicago: University of Chicago Press.

PACHON, Harry et al. 200o. Still Missing in Action: Latinos in and out of Hollywood. Los Angeles: Tomás Rívera Policy Institute and Screen Actors Guild.

PISCITELLI, Adriana. 2007. "Corporalidade em confronto: brasileiras na indústria do sexo na Espanha". Revista Brasileira de Ciências sociais, 22(64): 17-32. Available at: http:/|www.scielo.br/pdf/rbcsoc/v22n64/ ao2v2264.pdf Accessed on January 302020. . 2013. Trânsitos: brasileiras nos mercados transnacionais do sexo. Rio de Janeiro: EdUERJ/ Garamond/CLAM.

REZENDE, Claudia Barcellos. 2009. Retratos do Estrangeiro: identidade brasileira, subjetividade e emoção. Rio de Janeiro: FGV.

RIBEIRO, Gustavo Lins. 1999. “O que faz o Brasil, Brazil: Jogos Identitários em São Francisco”. In: R. R. Reis; T. Sales (orgs.), Cenas do Brasil Migrante. São Paulo: Boitempo. pp. 45-86.

SALES, Teresa. 1999. "Identidade étnica entre imigrantes brasileiros nos EUA”. In: R. R. Reis; T. Sales (orgs.), Cenas do Brasil Migrante. São Paulo: Boitempo. pp.17-44.

TIRIBA, Thais. 2017. Uma atraente esposa brasileira ou seu dinheiro de volta: uma análise de agências de casamento especializadas em unir mulheres brasileiras a homens alemães. Dissertação de Mestrado. Faculdade de Filosofia, Letras e Ciências Humanas da Universidade de São Paulo - São Paulo. 


\section{Documents}

BUREAU OF LABOR STATISTICS. 2018. Usual weekly earnings of wage and salary workers, second quarter 2018. U. S. Department of Labor.

MINISTÉRIO DAS RELAÇÕES EXTERIORES (MRE). Brasileiros no Mundo - Estimativas. 2014. SubsecretariaGeral das Comunidades Brasileiras no Exterior (SGEB), Departamento Consular e de Brasileiros no Exterior (DCB); Divisão de Assistência Consular (DAC).

U. S. CENSUS BUREAU. American Community Survey (ACS). 2014. Available at: <https:||factfinder.census.gov/ faces/tableservices/jsf/pages/productview.xhtml?pid=ACS_14_5YR_B05006\&prodType=table>Accessed on January 292020.

\section{Bernardo Fonseca Machado}

Postdoc at University of Campinas, Department of Anthropology, Institute of Philosophy and Human Sciences, Campinas/SP, Brazil.

https://orcid.org/oooo-0001-8884-2357

E-mail: bernardofmachado@gmail.com 